\title{
Macrozoobenthos on an intertidal mudflat in the Danish Wadden Sea: comparisons of surveys made in the 1930s, 1940 s and 1980s
}

\author{
K. Thomas Jensen \\ Institute of Biological Sciences, Department of Ecology and Genetics, University of \\ Aarhus; Ny Munkegade, Building 540, DK-8000 Aarhus C., Denmark
}

\begin{abstract}
To assess whether long-term faunal changes have occurred on intertidal flats in the Danish Wadden Sea, results of faunal surveys in the Skallingen area during the 1930s, 1940s and 1980 s were compared. Since the earlier studies, two species have disappeared (Scrobicularia plana and Petricola pholadiformis) and two have invaded the area (Tharyx killariensis and Ensis americanus). This is, however, not a local event as species changes have occurred on a larger scale (Wadden Sea region). Comparison of abundance data did not provide evidence of changes from the 1930s until the 1980s. Spatio-temporal fluctuations in two dominant species, the mudsnail Hydrobia ulvae and the cockle Cerastoderma edule chosen for closer examination, could be explained by natural processes. Growth data on cockles from the 1930 s and the 1980 s matched perfectly. During both periods, cockles showed a much lower growth rate than gererally reported from the Wadden Sea, while at the same time they occurred at high densities $\left(>2000\right.$ ind $\left.\cdot \mathrm{m}^{-2}\right)$. Intraspecific competition among cockles is suspected as being a major cause of the low growth rates. Estimates of secondary production and P/B-ratios of cockles were also in general agreement during the 1930s and the 1980 s when corrected for differences in the age structure of the cockle populations. With the possible exception of Mytilus edulis, which according to some observations has extended its range along the low-water line, the present comparison failed to demonstrate long-term faunal changes caused by increased eutrophication. This results is expected to be representative for intertidal flats not exposed to direct impacts from terrestrial run-offs and waste-water discharges.
\end{abstract}

\section{INTRODUCTION}

The Dutch-German-Danish Wadden Sea area is important for a variety of species including shorebirds, fish, shrimps and crabs because of its high benthic productivity. Being an area of international significance to migrating birds and stocks of North Sea fish, there is a growing concern regarding possible threats to this particular ecosystem. Like several other near-coastal areas the Wadden Sea has been increasingly exposed to human activities with possible resulting detrimental effects on the benthos. Loading by nutrients and organic substrates from terrestrial run-offs and waste-water discharges, in particular, have been reported to influence the macrozoobenthos (Essink \& Beukema, 1986; Madsen \& Jensen, 1987; Beukema, 1989, 1991; Esselink et al., 1989). Furthermore, dredging activities and fishery on mussels, cockles and shrimps have either directly (through overexploitation) or indirectly (through the effects of fishing equipment on the sea bottom) been considered detrimental to the benthic community (Reise, 1982, Vlas, 
1987; van der Veer et al. 1985). In subtidal areas of the German Wadden Sea, considerable faunal changes have occurred during the last 60 years that are mainly attributable to human activities (Riesen \& Reise, 1982; Reise \& Schubert, 1987). While faunal impoverishment has often been reported to follow prolonged and severe eutrophication in nearcoastal sublittoral areas, this would not be a predictable effect on the intertidal fauna because of mixing by tidal currents. Accordingly, studies in the Dutch Wadden Sea have shown an increase in the abundance and secondary production of several intertidal flat species during the last 20 years to be a result of eutrophication (Beukema \& Cadeé, 1986; Beukema, 1989, 1991). During the same period, the concentration of phytoplankton and the primary production of the microphytobenthos in the Dutch Wadden Sea have almost doubled (Cadeé, 1984, 1986a, b).

Although the utilization of the Danish Wadden Sea has, until quite recently, been less intensive compared with the Dutch and German parts, it nonetheless receives large amounts of nutrients and organic substrates from terrestrial sources (Henriksen et al., 1984). So far, no studies of long-term faunal changes in the Danish Wadden Sea have been reported. In an attempt to assess whether faunal changes have occurred on tidal flats in the Danish Wadden Sea, and to what extent such changes have been generated by human activities, I compared the results of two earlier faunal investigations with a more recent one. The tidal flats on the east coast of Skallingen (the northern part of the Danish Wadden Sea) were investigated during the early 1930s by Thamdrup (1935). In the 1940s Smidt (1951) performed a more extensive faunal survey in this area, and I sampled the fauna at Skallingen from 1982 to 1985 . Since the study area is not under direct influence from any sewage outlet or polluted terrestrial run-off, any long-term faunal changes ought to reflect either natural processes or effects of a more general human impact on the ecosystem. Data on species cómposition and abundance of the macrofauna are compared. Furthermore, two dominant macrofaunal species, Hydrobia ulvae (Prosobranchia) and Cerastoderma edule (Bivalvia), are examined in more detail with respect to population dynamics (both species) and growth and secondary production (C. edule). These species each represent a separate part of the ecosystem, being a deposit-feeder and a suspension-feeder, respectively. Furthermore, $H$. ulvae dominates the upper intertidal zone whereas $C$. edule dominates the lower zone (Thamdrup, 1935).

\section{AREA AND METHODS}

The macrozoobenthos on the tidal flat east of the Skallingen peninsula in the northern part of the Danish Wadden Sea $\left(55^{\circ} 30^{\prime} \mathrm{N}, 8^{\circ} 18^{\prime} \mathrm{E}\right.$, Fig. 1) has been examined previously by Thamdrup (1935) and Smidt (1951). During the period from 1982 until 1985. I quantitatively sampled the benthos along an intertidal transect in the vicinity of Thamdrup's "Fernsprechhaus-linie" (Fig. 1). Details on sampling procedures can be found elsewhere (Thamdrup, 1935; Smidt, 1951; Jensen \& Jensen, 1985; Jensen, 1992). Small samples taken by Thamdrup (1935) were sieved through a $0.9 \mathrm{~mm}$ sieve, whereas Smidt (1951) used a $1 \mathrm{~mm}$ sieve for those samples reported here. I used a mesh size of $0.5 \mathrm{~mm}$ for small samples $\left(21 \mathrm{~cm}^{2}\right)$ and $1 \mathrm{~mm}$ for larger samples $\left(143 \mathrm{~cm}^{2}\right)$. Data on the quantitative occurrence of the macrobenthos have been read from Figures in Thamdrup (1935, p. 75-97) and from Table 18 in Smidt (1951). The shell lengths of cockles were taken from Figure 25, p. 75 in Thamdrup (1935) and Figure 34, p. 80 in Smidt (1951). 


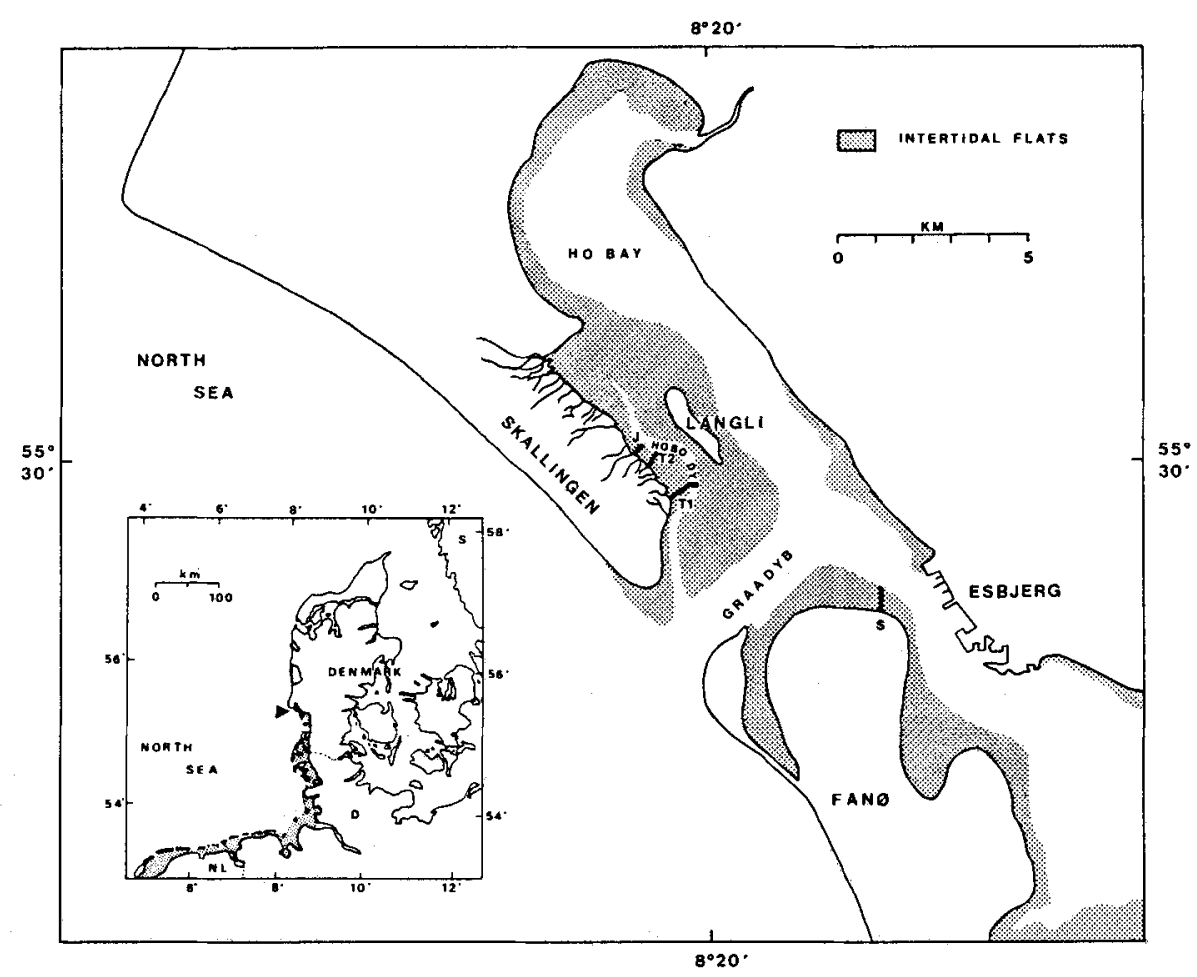

Fig. 1. Map of the northern part of the Danish Wadden Sea area showing the location of the studied transect $(J)$ and those transects studied by Thamdrup (1935) (T1: "Buhnen-Linie", T2: "Fernsprechhaus-linie") and Smidt (1951) (S)

Benthic samples were collected along two 500-m-long transects (Thamdrup, 1935; Smidt, 1951) and along one 400-m-long transect (1982-85) from the high-water line (HWL) to the low-water line (LWL). The transect used in 1982-85 was similar to the "Buhnen-linie" (Thamdrup, 1935) with respect to sediment composition. In the upper half of the intertidal flat the sediment was dominated by fine sand grains (mean grain size about $180 \mu \mathrm{m}$ and silt content below $2 \%$ ) while the substratum was muddier at the lower flat (mean grain size about $130 \mu \mathrm{m}$ and silt content near $30 \%$, St. $300 \mathrm{~m})(1982-85$, Jensen, 1992). The "Fernsprechhaus-linie" was a pure sand-flat with coarse sand grains $(200-500 \mu \mathrm{m})$ as the dominant sediment fraction (Thamdrup, 1935). Smidt (1951) collected samples along the same transects as were used by Thamdrup. There are no remarks in Smidt (1951) concerning sediment composition when he collected samples in August 1942. The tidal range in this area is about $1.5 \mathrm{~m}$.

Available data on densities and length of cockles (Figs 3 and 4) during the 1930s and the 1980 s were used to calculate a rough estimate of secondary production during the two periods. The mean weights of cockles were estimated from their mean lengths using the following length-weight equation: $\ln \mathrm{W}=-5.61+3.15 \ln \mathrm{L}$ (W in $\mathrm{mg}$ flesh $\mathrm{ADW}$; $\mathrm{L}$ in $\mathrm{mm}$ ), obtained from formaldehyde preserved specimens collected in October 1984 at St. 
$300 \mathrm{~m}$ (Jensen, in prep.). The secondary production between two dates $t_{1}$ and $t_{2}$ (separated by one year) is calculated as the product of the mean weight increment $(\Delta w)$ and the number of individuals living between $t_{1}$ and $t_{2}$. To give the possible range in production, three estimates are calculated, assuming: (1) that the number of cockles growing between $t_{1}$ and $t_{2}$ is equal to the mean density at $t_{1}$ and $t_{2}$ (mean estimate); (2) that all cockles living at $t_{1}$ survived until immediately before $t_{2}$ (maximum estimate); (3) that only those present at $t_{2}$ lived during the whole period (minimum estimate). The mean estimate of production is also used to calculate the P/B-ratio.

\section{RESULTS}

\section{Macrozoobenthos at Skallingen in the 1930s, 1940s and 1980s}

The macrozoobenthic species living on the intertidal flat at Skallingen are dominated by typical members of the 'Macoma balthica' community (Table 1). Most of the species show characteristic distributional patterns along the intertidal gradient. Species such as Pygospio elegans, Hydrobia ulvae and Corophium volutator generally attain their highest numbers in the upper intertidal zone, whereas species like Cerastoderma edule and Mya arenaria increase in abundance in an off-shore direction. Mytilus edulis occurs in beds along the low-water line. During both faunal surveys in the 1930s and in the 1980s, cockles were the most important species quantitatively on the lower shore, whereas $H$. ulvae dominated on the upper shore.

L osses. Two species were recorded only during the 1930s (Scrobicularia plana and Petricola pholadiformis) and one species was observed only in the 1940s (Cirratulus cirratus) (Table 1). As this latter species was represented by a few juvenile individuals only, I will consider its occurrence as accidental. However, the absence of species from samples does not necessarily indicate that they have vanished from the area. I did not find S. plana or $P$. pholadiformis even though I have sampled regularly in this area for 3 years. $P$. pholadiformis was observed for the first time in the Skallingen area in 1905; it was common from 1910 and onwards (Jensen \& Spärck, 1934, cit. by Thamdrup, 1935), but was observed only once by Thamdrup (1935). S. plana occurred in low densities during the 1930s on silty substrata (Thamdrup, 1935).

Gains. Three species (Polydora ligni, Tharyx killariensis and Corophium arenarium) were not mentioned in the earlier studies but were found during the surveys in 1982 and 1983. (It is assumed that both Capitella capitata and Heteromastus filiformis were included in Capitellidae and that Eteone longa and Anaitides maculata were included in Phyllodocidae in the data reported by Smidt, 1951). P. ligni might have been overlooked during the earlier surveys although Smidt (1951) found $P$. ligni from nearby localities. T. killariensis is identical to the species which hitherto has been described as Tharyx marioni sensu Farke, 1979 (M. E. Petersen pers. comm.). The genus Tharyx has recently been redescribed and restricted by Blake (1991). T. killariensis occurs in high densities at the lower intertidal flat on sites with a high silt-content. I have recorded maximum densities of 30000 ind $\cdot \mathrm{m}^{-2}$ (March 1983). C. arenarium was described in 1937 by Crawford (Crawford, 1937) but was not mentioned by Smidt (1951). However, Stock (1952) found $C$. arenarium in Ho Bugt in 1952. Therefore, it is probable that the species was confused with Corophium volutator during the earlier surveys. 
$\mathrm{Ch}$ anged a bund a n ce. Nereis diversicolor, Scoloplos armiger and members of the family Capitellidae were recorded in maximum densities in 1982-83, being more than $100 \%$ higher than those reported in the earlier investigations. The presence of high numbers of juveniles, i. e. those individuals retained on a $0.5 \mathrm{~mm}$ mesh but not on sieves with larger mesh sizes, could contribute to the observed density differences. The high numbers of spat of $C$. edule and $M$. balthica both in 1942 and in 1982 followed severe winters in 1941/42 and 1981/82, respectively. In 1982 and 1983 the abundance of $C$. volutator was low on the intertidal flat compared with its abundance during the previous surveys. However, this species is subject to great spatiotemporal fluctuations. It was observed at high densities in tidal creeks at Skallingen in 1982 and 1983 (own obs.).

\section{Temporal and spatial variation in population dynamics and growth}

Hydrobia ulvae. The interannual variation in the abundance of $H$. ulvae is large. Samples taken in July during the period from 1931 to 1934 in the upper tidal zone showed a variation from 5000 to almost 50000 ind $\cdot \mathrm{m}^{-2}$ (Fig. 2). Within one year I found a variation of the same magnitude (from 15000 to 65000 ind $\cdot \mathrm{m}^{-2}$ ). Observations by Thamdrup (1935) suggest that $H$. ulvae is limited to the upper part of the intertidal flat. However, the distributional pattern reported by Smidt (1951) from an intertidal flat in the northern part of Fanø showed their presence in the lower intertidal zone, also. From monthly data on abundance of $H$. ulvae along the intertidal gradient at Skallingen, 1982-83, it appears that for peak density at each site there is a successive progression in a landward direction starting at station $300 \mathrm{~m}$ (Fig. 2). This pattern ist presumably due to a settlement of $H$. ulvae in the lower intertidal zone followed by a net landward migration.

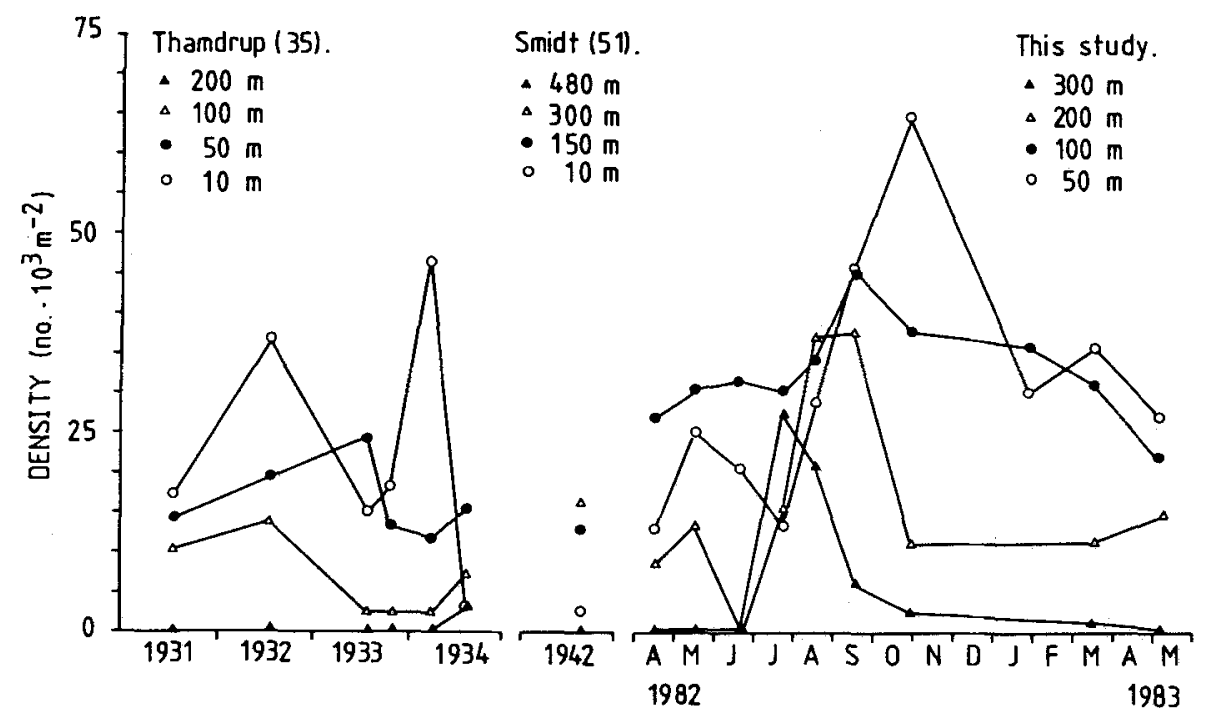

Fig. 2. Seasonal and long-term patterns in density (no. $\cdot \mathrm{m}^{-2}$ ) of Hydrobia ulvae at Skallingen (symbols indicate sampling positions in metres from the MHWL) 
Table 1. Macrobenthic species at Skallingen during the 1930s, the 1940s and the $1980 \mathrm{~s}$. All values are maximum numbers (ind $\cdot \mathrm{m}^{-2}$ ) along the transects for July or August. Ranges given for data from the 1930 s and the 1980s denote the lowest and the highest maximum density registered in July during the study periods. If only a single value is indicated it represents the maximum numbers mentioned by the author. Juv.: 0-group; adu.: 1-year and older; "-": not mentioned; obs: observed

\begin{tabular}{|c|c|c|c|c|c|}
\hline & \multicolumn{2}{|c|}{ Thamdrup, July 1931-35 } & \multicolumn{2}{|c|}{ Smidt, August 1942} & \multirow{2}{*}{$\begin{array}{l}\text { Jensen, } \\
\text { July 1982-83 }\end{array}$} \\
\hline & Transect 1 & Transect 2 & Transect 1 & Transect 2 & \\
\hline \multicolumn{6}{|l|}{ Oligochaeta } \\
\hline Tubificoides benedeni & - & - & - & - & $4000-9000$ \\
\hline Oligochaeta sp. & - & - & 6200 & 2500 & $2000-12000$ \\
\hline \multicolumn{6}{|l|}{ Polychaeta } \\
\hline Phyllodocidae & - & - & 900 & 250 & \\
\hline Eteone longa & - & - & - & - & $440-520$ \\
\hline Anaitides maculata & - & - & - & - & $0-140$ \\
\hline Nereis diversicolor & $100-280$ & $30-70$ & 500 & 530 & $2000-3800$ \\
\hline Nephtys hombergi & 90 & $7-13$ & 30 & 0 & 50 \\
\hline Scoloplos armiger & 100 & $370-460$ & 4900 & 1700 & $1600-15000$ \\
\hline Polydora ligni & - & - & - & - & $670-1200$ \\
\hline Pygospio elegans & $15000-20000$ & 6000 & 2300 & 5600 & $3400-22000$ \\
\hline Cirratulus cirratus & - & - & 200 & 0 & 0 \\
\hline Tharyx killariensis & - & - & - & - & $1300-5000$ \\
\hline Capitellidae & & & 1800 & 1000 & \\
\hline Capitella capitata & - & - & - & - & $260-9000$ \\
\hline Heteromastus filiformis & 40 & 0 & - & - & $620-880$ \\
\hline Arenicola marina & $25-100$ & 38 & 14 & 34 & $30-31$ \\
\hline Pectinaria koreni & - & - & $300^{\prime}$ & 0 & 0 \\
\hline Lanice conchilega & obs. & - & 70 & 0 & $0-50$ \\
\hline \multicolumn{6}{|l|}{ Gastropoda } \\
\hline Hydrobia ulvae & $16000-37000$ & $350-1000$ & 16000 & 10000 & $5800-31000$ \\
\hline Littorina Iittorea ${ }^{\circ}$ & $7-70$ & obs. & - & - & $10-16$ \\
\hline Retusa obtusa & - & - & 250 & 170 & $50-90$ \\
\hline \multicolumn{6}{|l|}{ Bivalvia } \\
\hline \multirow{2}{*}{$\begin{array}{r}\text { Cerastoderma edule juv. } \\
\text { adu. }\end{array}$} & few -2700 & few -250 & 72000 & 64000 & $300-62000$ \\
\hline & $1300-4700$ & $250-1500$ & 70 & 0 & $0-4300$ \\
\hline \multirow{2}{*}{$\begin{array}{c}\text { Macoma balthica juv. } \\
\text { adu. }\end{array}$} & $300-5700$ & 230 & 55000 & 23000 & $0-2650$ \\
\hline & $350-1000$ & 75 & 700 & 530 & $1100-1200$ \\
\hline \multirow[t]{2}{*}{ Mya arenaria } & 110 & 0 & 8800 & 0 & $0-17000$ \\
\hline & $13-20$ & $0-13$ & 0 & 0 & $30-50$ \\
\hline Scrobicularia plana & 60 & 0 & 0 & 0 & 0 \\
\hline Mytilus edulis & beds & no beds & beds & - & beds \\
\hline Petricola pholadiformis & obs. & 0 & 0 & 0 & 0 \\
\hline \multicolumn{6}{|l|}{ Crustacea } \\
\hline Corophium volutator & $1000-3200$ & $300-1100$ & 9200 & 17400 & $200-440$ \\
\hline Corophium arenarium & - & - & - & - & $100-1700$ \\
\hline Bathyporeia spp. & obs. & obs. & 0 & 200 & 0 \\
\hline \multicolumn{6}{|l|}{ Nemertina } \\
\hline Nemertini sp. & - & - & 100 & 100 & $50-260$ \\
\hline
\end{tabular}


Both Smidt (1951) and Reise (1987) observed that juveniles of $H$. ulvae occurred predominantly in the lower tidal zone. The natural variation in the quantity of larvae and the time of settlement may cause interannual differences in their distributional pattern. Thus, the peak density along a tidal gradient does not necessarily occur at the same site in a certain month each year. For example, severe winters may reduce the survival of $H$. ulvae disproportionately in the upper intertidal zone compared with the lower zone (Smidt, 1951). This could be an explanation for the distributions observed in 1942 and again in spring 1982 compared with the distribution in the 1930s. From September 1982 and onwards, the distribution along the intertidal gradient was similar to the distribution observed by Thamdrup (1935). As Thamdrup apparently missed the juveniles during the sampling in July because they could pass through his sieve, he would probably not detect individuals present in the lower intertidal zone. However, he does mention that among snails found on the lower flat a higher fraction belonged to the 0-group. Difference in mesh sizes may also explain the higher densities observed during the 1980 s than during earlier investigations. The cause of the landward migration of $H$. ulvae is probably the presence of dense populations of large diatoms on the upper shore, these being important food items for $H$. ulvae (Jensen, 1980). Individual mudsnails move faster on substrata with poor food than on substrata rich in food items. This mechanism may gradually cause an accumulation of snails on sites with dense populations of diatoms (Jensen, 1980). In conclusion, there is no evidence that the abundance pattern of $H$. ulvae has changed since the 1930s.

Cerastoderma edule. In the years 1931 to 1935, two year classes of cockles (1928 and 1929) dominated the population of cockles at Skallingen (Thamdrup, 1935). During my study from 1982 until 1985, only one year class of cockles occurred (Jensen, 1992). This year class settled in July 1982 and it was exterminated during the winter 1984-85. Together, these investigations provide data on abundance and growth of cockles from their settlement until six years old (Figs 3 and 4).

In July 1982 , the density of juvenile cockles was about 35000 ind $\cdot \mathrm{m}^{-2}$ at St. $200 \mathrm{~m}$ and St. $300 \mathrm{~m}$ from the shoreline. Due to predation by juvenile crabs, the densities declined rapidly during August and September (Jensen \& Jensen, 1985). After this time, there was a more gradual reduction in densities. In autumn 1984 the numbers at the lower sites varied from 2000 to $3000 \mathrm{ind} \cdot \mathrm{m}^{-2}$. Thamdrup (1935) found densities of cockles older than 2 years in the range of 2000 to 4500 ind $\cdot \mathrm{m}^{-2}$ in the lower tidal zone. The densities of cockles along the "Fernsprechhaus-linie" were much lower than those along the "Buhnen-linie" (Thamdrup, 1935).

Data on lengths of cockles from their settlement until an age of 2 years (Jensen, 1992) have been combined with data provided by Thamdrup (1935) on the temporal variation in mean lengths of year class 1928 during 1931 to 1935 ( 3 to 6 years old) (Fig. 4). These sets of data agree quite well. Two- and six-year-old cockles on this mudflat reached maximum mean lengths of 18.4 and $22.5 \mathrm{~mm}$, respectively. In comparison, a low-density population of cockles from the north coast of Fano reached a mean shell length of about $27 \mathrm{~mm}$ after only two years (Fig. 1 and Smidt, 1951). This is more in accordance with growth patterns reported by other authors (Orton, 1926, Kreger, 1940; Kristensen, 1957). In addition, high growth rates in cockles were observed on the same transect in 1989. Cockles collected in October 1989 had reached a mean length of $30.3 \mathrm{~mm}$ after three growing seasons (St. $300 \mathrm{~m}$ ). This difference in growth rates of cockles from the same 


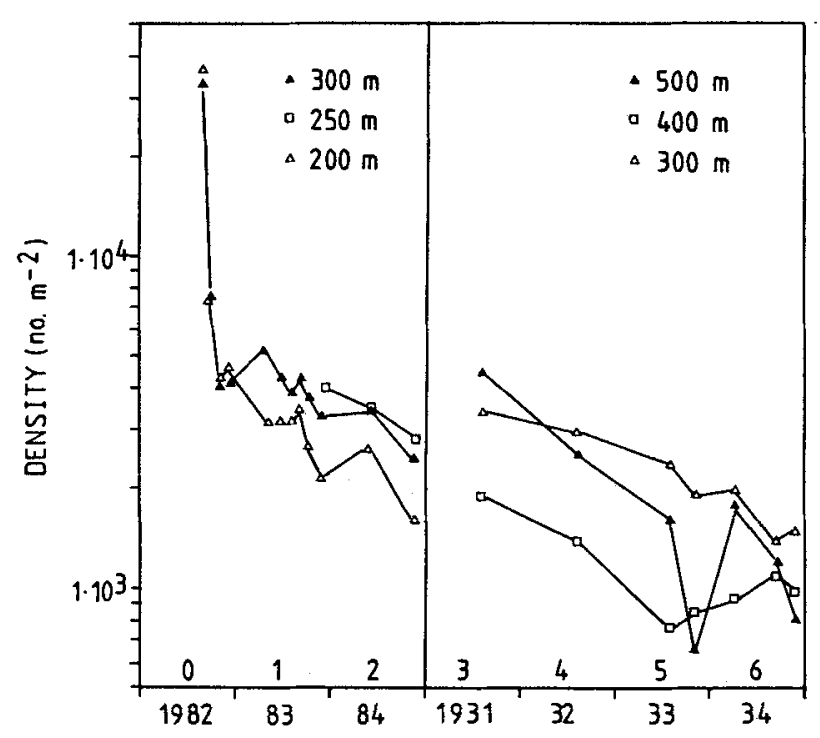

Fig. 3. Density (no. $\cdot \mathrm{m}^{-2}$ ) of Cerastoderma edule at Skallingen during 1982-84 (0- to 2-yr-old cockles) and 1931-34 (3- to 6-yr-old cockles). The transect studied in the 1930s was $\approx 500 \mathrm{~m}$-long, while the one studied in $1980 \mathrm{~s}$ was $\approx 400 \mathrm{~m}$-long. (Symbols indicate sampling positions in metres from MHWL)

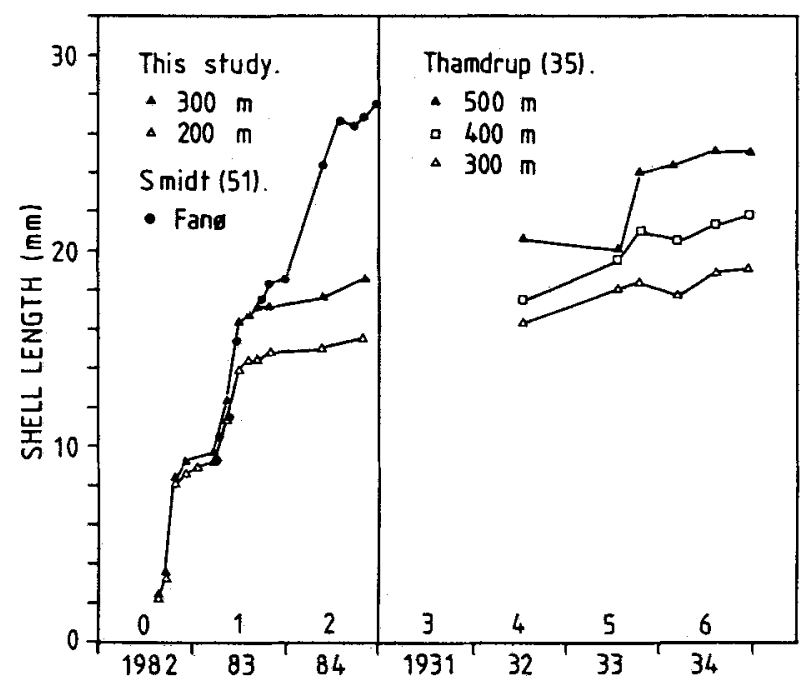

Fig. 4. Mean shell length of cockles during 1982-84 (0- to 2-yr-old cockles) and 1932-34 (4- to 6-yrold cockles). In addition, length data (1- and 2-yr-old cockles in 1946, Fig. 34, Smidt, 1951) from a cockle population on the north coast of Fanø (Fig.1) are plotted. Densities of the Skallingen populations can be read from Figure 3 . The population at Fanø reached a maximum density of $\approx 500$ ind $\cdot \mathrm{m}^{-2}$ (June 1946, Smidt, 1951, p. 83) 
Table 2. Estimates of average biomass, annual secondary production and P/B-ratios of cockles during 1932-33 (St. $300 \mathrm{~m}$ and St. $400 \mathrm{~m}$ ) and 1983-84 (St. $200 \mathrm{~m}$ and St. $300 \mathrm{~m}$ ) at Skallingen

\begin{tabular}{|ccccc|}
\hline & \multicolumn{2}{c}{$\begin{array}{c}\text { Biomass } \\
\left(\mathrm{g} \mathrm{ADW} \mathrm{m}^{-2}\right)\end{array}$} & $\begin{array}{c}\text { Production } \\
\left(\mathrm{g} \mathrm{ADW} \mathrm{m}^{-2}\right)\end{array}$ & P/B \\
\hline & July 32 & July 33 & & \\
$1932-33$ & 68.5 & 78.3 & $24.8(22.3-27.3)$ & 0.34 \\
$300 \mathrm{~m}$ & 40.9 & 33.6 & $15.8(11.2-20.4)$ & 0.42 \\
$400 \mathrm{~m}$ & May 83 & May 84 & & \\
& & & & \\
$1983-84$ & 24.0 & 45.7 & $27.9(25.4-30.3)$ & 0.80 \\
$200 \mathrm{~m}$ & 41.3 & 102.5 & $74.4(69.2-85.7)$ & 1.04 \\
$300 \mathrm{~m}$ & & & & \\
\hline
\end{tabular}

Table 3. Estimates of average biomass, secondary production and P/B-ratios of cockles during the period from May to October in 1983 and 1984 (St. $200 \mathrm{~m}$ and St. $300 \mathrm{~m}$ ) at Skallingen

\begin{tabular}{|c|c|c|c|c|}
\hline & \multicolumn{2}{|c|}{$\begin{array}{c}\text { Biomass } \\
\text { (g ADW m }{ }^{-2} \text { ) }\end{array}$} & \multirow[t]{2}{*}{$\begin{array}{c}\text { Production } \\
\left(\text { g ADW m }^{-2}\right)\end{array}$} & \multirow[t]{2}{*}{$\mathrm{P} / \mathrm{B}$} \\
\hline & May 83 & Oct 83 & & \\
\hline \multicolumn{5}{|l|}{1983} \\
\hline $200 \mathrm{~m}$ & 24.0 & 36.3 & $24.3(19.7-28.8)$ & 0.81 \\
\hline \multirow[t]{2}{*}{$300 \mathrm{~m}$} & 41.3 & 89.5 & $66.1(57.6-74.6)$ & 1.01 \\
\hline & May 84 & Oct 84 & & \\
\hline \multicolumn{5}{|l|}{1984} \\
\hline $200 \mathrm{~m}$ & 45.7 & 31.6 & $6.4(4.7-8.1)$ & 0.17 \\
\hline $300 \mathrm{~m}$ & 102.5 & 86.4 & $15.1(12.6-17.6)$ & 0.16 \\
\hline
\end{tabular}

locality is probably a result of density-dependent growth regulation in cockles because fewer than 32 ind $\cdot \mathrm{m}^{-2}$ were present in 1989 (Jensen, 1992, and in prep.).

Data on density and growth of cockles have been combined to estimate annual secondary production at two stations in 1932-33 and 1983-84 (Table 2). From this it appears that the production was higher in 1983-84 than in 1932-33, suggesting a higher production of food items (phytoplankton). P/B ratios seem to support this. However, it should be noted that the cockles from 1932-33 were older than those from 1983-84. A comparison of the secondary production during the periods May to October 1983 and 1984 confirms that productivity decreases with the age of cockles (Table 3). For this reason, the present data would not support less food production during the 1930s than during the 1980s.

\section{DISCUSSION}

Two species appear to have vanished from the Skallingen area since the 1930s, namely Petricola pholadiformis and Scrobicularia plana, and one has emerged, namely Tharyx killariensis. In addition, Ensis americanus (previously misidentified as Ensis 
directus; see van Urk, 1987), has recently been reported from the Hobo-Dyb tidal area (Rasmussen, unpublished). Two of these species ( $P$. pholadiformis and E. americanus) are exotic species as originally they were immigrants from USA. $P$. pholadiformis was already on the decline during the 1930s (Thamdrup, 1935). Lack of specific adaptations to new environments with respect to abiotic factors or disease agents (e.g. local parasite community) may eventually cause the local extinction of foreign species. The two new species (T. killariensis and E. americanus) were first observed during the late 1960 s and 1970 s (Farke, 1979; Essink, 1985; Reise, 1985; Swennen et al., 1985). The decline in S. plana seems to be a widespread phenomenon as it has also been reported to have disappeared from other regions of the Wadden Sea (Essink et al., 1991; Reise, 1982). However, increased numbers have been reported from some Dutch areas (Beukema \& Cadeé, 1986). Presently, there are no clues as to these opposite trends in occurrence (Essink et al., 1991).

Two deposit-feeding groups of polychaetes (Scoloplos armiger and Capitellidae) and one omnivorous polychaete (Nereis diversicolor) showed considerably higher densities in the early 1980s than previously registered. Part of this increase could be due to higher numbers of juveniles during the latest survey because of the smaller mesh size used. On the other hand, increased numbers of these species have also been reported from the tidal flats near Sylt and from the Dutch Wadden Sea (Reise et al., 1989; Beukema, 1989).

The abundance patterns and dynamics of populations of Hydrobia ulvae and Cerastoderma edule were similar during the surveys in the 1930s and the early 1980s. In addition, the growth pattern of cockles followed the same trajectory during these periods. In both periods, cockles exhibited extremely low growth rates. This has been interpreted as a result of a negative density-dependent mechanism, probably as a result of food competition (Jensen, 1992 and in prep.). The growth'data of cockles strongly support great similarity during the early 1930 s and 1980s in terms of environmental conditions. Assuming that eutrophication and, in turn, increased primary production would enhance growth rates in suspension-feeders from intertidal flats, as shown in Macoma balthica (Beukema \& Cadeé, 1986, 1991), the present results suggest that the same amount of food was available to cockles in the 1930 s and 1980 s. This is also largely corroborated by the estimates of secondary production. Considering the age of cockles living from July 1932 to July 1933, they exhibited a high secondary production. The $\mathrm{P} / \mathrm{B}$ ratios also support the suggestion that cockles from the 1930s were at least as productive as those from the 1980s.

The present faunal comparison does not suggest that major alterations in faunal structure and function occurred during the period from the 1930s to the 1980s on the studied mudflat. Nonetheless, intercontinental shipping is the ultimate cause of the appearance of some new species in the present ecosystem. Apart from this, variability caused by natural processes may explain most of the observed differences in densities. However, it remains possible that the increased numbers in three polychaete groups could be a result of increased eutrophication (Beukema; 1991).

No long-term studies of primary production have been conducted in the Danish Wadden Sea. The Hobo-Dyb tidal area is supplied directly with coastal water from the Graadyb tidal inlet. Henriksen et al. (1984) have measured levels of phytoplankton production in Graadyb that exceed measurements in the tidal inlet Marsdiep in the western Dutch Wadden Sea from the mid-1970s (Henriksen et al., 1984). However, later 
reports from the Marsdiep area indicate an increase by a factor 2 in phytoplankton production from the mid 1970s until the early 1980s (Cadeé, 1986b) due to increased supplies of phosphate. Thus, phytoplankton production reached comparable high levels in the tidal inlet of Marsdiep and Graadyb in the early 1980s. The high phytoplankton production in Graadyb is a result of high nutrient supplies from the river Varde $\AA$ and from the city of Esbjerg (Henriksen et al., 1984; Pejrup et al., 1990). As these supplies have increased since the faunal investigations during the 1930s and 1940s due to the use of fertilizers in agriculture and increased amounts of sewage discharge, it seems reasonable to assume that the phytoplankton production also has increased. Faunal studies from the western Dutch Wadden Sea have indicated long-term trends of increasing biomass, densities and growth rates of several intertidal flat species in response to the increased primary production since 1970 (Beukema, 1991). However, a study from the eastern Dutch Wadden Sea failed to detect long-term faunal trends despite increased eutrophication (de Jonge \& Essink, 1991). To consider why the present study failed to detect any such changes, a few shortcomings should be mentioned. For example, data in Table 1 are strongly simplified as spatiotemporal fluctuations are ignored. In fact, most species are subject to large fluctuations in abundance due to natural processes. The conclusions arrived at are also based on subjective interpretations rather than on rigorous statistical tests. It is possible that the years of comparison are atypical and therefore fail to reveal any long-term trends overriding the multitude of factors otherwise influencing the benthos. The approach adopted by comparing more detailed abundance data in two dominant invertebrates, $H$. ulvae and $C$. edule, and growth data of cockles, summarising data for longer periods than those in Table 1, albeit in a few species only, is more likely to reveal real trends.

The question remains as to whether other species not'examined in detail could have responded to increased eutrophication. Remarks on the distribution of mussels (Mytilus edulis) during the 1930s (Thamdrup, 1935) and 1940s (Smidt, 1951) and my own observations during the 1980 s suggest that this species has extended its range along the Hobo-Dyb channel. There were mussel beds along the low-water line in the 1980s at the studied transect. However, Figure 2 in Thamdrup (1935) and comments by Smidt (1951) suggest that during their studies mussels were more or less restricted to the southern edge of the Hobo-Dyb tidal channel. Mussels might therefore have taken advantage of the higher primary production in this area. Expansion of mussel beds along the low-water line has also been reported from the German area (Reise et al., 1989).

The two transects studied by Thamdrup (1935) exhibited different faunal compositions. In the 1930s, the transect named "Fernsprechhaus-linie" was more sandy and homogeneous along the tidal gradient than the other transect ("Buhnen-linie"). The transect studied during 1982-85 was almost identical to the "Buhnen-linie" with respect to sediment and faunal composition, though it was situated closer to the "Fernsprechhaus-linie". Spread of mussel beds since the 1930s along the Hobo-Dyb tidal channel could have caused increased sedimentation on the lee-side of the mussel beds, and in turn could have brought about a change in faunal composition.

According to Dankers \& Koelemaij (1989), mussels often occur in such densities that they influence the whole ecosystem. In some years they may filter the entire water volume every few days. Thus, they may influence the amount of food available for other organisms. The high densities of cockles as reported here would suggest that they also 
might influence the phytoplankton biomass. Other studies support the idea that dense assemblages of suspension-feeding organisms may exert some control on the phytoplankton biomass and primary production (Cloern, 1982; Officer et al., 1982). In addition, it has been experimentally demonstrated that high densities of cockles may reduce the settlement of their own larvae (André \& Rosenberg, 1991) as well as Macoma balthica larvae (Jensen, 1985). Furthermore, the burrowing and ploughing habits of cockles have detrimental effects on some species (Reise, 1983; Jensen, 1985). Therefore, both cockles and mussels may be key organisms in this particular ecosystem through their functional (regarding energy flow) and structural importance. Interannual variability in the numbers of these two species may cause variability in other species. In particular, other suspension-feeding organisms may suffer from food depletion due to high densities of either mussels or cockles. In other words, cockles and mussels may control the response of other organisms to increased eutrophication.

In conclusion, the present comparison failed to detect any major faunal changes caused by human impact since the 1930s. However, the limitation of the approach adopted has to be recognized. The comparison is based upon macrobenthic data collected from a single locality. Furthermore, the study area is situated far from any terrestrial run-offs and waste water discharges. Any changes, therefore, would at most reflect possible effects of a generally increased nutrient loading and, in turn, increase in primary production. Comparison of macrozoobenthic data from a larger area through a sequence of years would produce a more comprehensive picture.

Acknowledgements. I thank K.N. Moutitsen for valuable comments on the manuscript and J. Mather for correcting the English.

\section{LITERATURE CITED}

André, C. \& R. Rosenberg, 1991. Adult-larval interactions in the suspension-feeding bivalves Cerastoderma edule and Mya arenaria. - Mar. Ecol. Prog. Ser. 71, 227-234.

Beukema, J.J., 1989. Long-term changes in macrozoobenthic abundance on the tidal flats of the western part of the Dutch Wadden Sea. - Helgoländer Meeresunters. 43, 405-415.

Beukema, J.J., 1991. Changes in composition of bottom fauna of a tidal-flat area during a period of eutrophication. - Mar. Biol. 111, 293-301.

Beukema, J. J. \& Cadée, G. C., 1986. Zoobenthos responses to eutrophication of the Dutch Wadden Sea. - Ophelia 26, 55-64.

Beukema, J. J. \& Cadée, G. C., 1991. Growth rates of the bivalve Macoma balthica in the Wadden Sea during a period of eutrophication: relationships with concentrations of pelagic diatoms and flagellates. - Mar. Ecol. Prog. Ser. 68, 249-256.

Blake, J. A., 1991. Revision of some genera and species of Cirratulidae (Polychaeta) from the Western North Atlantic. - Ophelia (Suppl.) 5, 17-30.

Cadée, G. C., 1984. Has input of organic matter into the western part of the Dutch Wadden Sea increased during the last decades? - Publ. Ser. Neth. Inst. Sea Res. 10, 71-82.

Cadée, G. C., 1986a. Recurrent and changing seasonal patterns in phytoplankton of the westernmost inlet of the Dutch Wadden Sea from 1969 to 1985. - Mar. Biol. 93, 281-289.

Cadée, G. C., 1986b. Increased phytoplankton primary production in the Marsdiep area (Western Dutch Wadden Sea.) - Neth. J. Sea Res. 20, 285-290.

Cloern, J.E., 1982. Does the benthos control phytoplankton biomass in South San Francisco Bay? Mar. Ecol. Prog. Ser. 9, 191-202.

Crawford, G. I., 1937. A review of the amphipod genus Corophium, with notes on the British species. - J. mar. biol. Ass. U. K. 21, 589-630. 
Dankers, N. \& Koelemaij, K., 1989. Variations in the mussel population of the Dutch Wadden Sea in relation to monitoring of other ecological parameters. - Helgoländer Meeresunters. 43, 529-535.

Essink, K., 1985. On the occurrence of the American jack-knife clam Ensis directus (Conrad, 1843) (Bivalvia, Cultellidae) in the Dutch Wadden Sea. - Basteria 49, 73-80.

Essink, K. \& Beukema, J.J., 1986. Long-term changes in intertidal flat macrozoobenthos as an indicator of stress by organic pollution. - Hydrobiologia 142, 209-215.

Essink, K., Beukema, J.J., Coosen, J., Craeymeersch, J.A., Ducrotoy, J.-P., Michaelis, H. \& Robineau, B., 1991. Population dynamics of the bivalve mollusc Scrobicularia plana da Costa: comparisons in time and space. In: Estuaries and coasts: spatial and temporal intercomparisons. Ed. by M. Elliott \& J.-P. Ducrotoy. Olsen \& Olsen, Fredensborg, 167-172.

Esselink, P., Belkum, J. van \& Essink, K., 1989. The effect of organic pollution on local distribution of Nereis diversicolor and Corophium volutator. - Neth. J. Sea Res. 23, 323-332.

Farke, H., 1979. Population dynamics, reproduction and early development of Tharyx marioni (Polychaeta, Cirratulidae) on tidal flats of the German Bight. - Veröff. Inst. Meeresforsch. Bremerh. 18, 69-99.

Henriksen, K., Jensen, A. \& Rasmussen, M. B., 1984. Aspects of nitrogen and phosphorus mineralization and recycling in the northern part of the Danish Wadden Sea. - Publ. Ser. Neth. Inst. Sea Res. 10, 51-69.

Jensen, K.T., 1980. Aspekter of Hydrobia ulvae's og Corophium volutator's okologi i Vadehavet. Thesis, Univ. of Aarhus, $121 \mathrm{pp}$.

Jensen, K. T., 1985. The presence of the bivalve Cerastoderma edule affects migration, survival and reproduction of the amphipod Corophium volutator. - Mar. Ecol. Prog. Ser. 25, 269-277.

Jensen, K. T., 1992. Dynamics and growth of the cockle, Cerastoderma edule, on an intertidal mudflat in the Danish Wadden Sea: effects of submersion time and density. - Neth. J. Sea Res. 28, 335-345.

Jensen, K. T. \& Jensen, J.N., 1985. The importance of some epibenthic predators on the density of juvenile benthic macrofauna in the Danish Wadden Sea. - J. exp. mar. Biol. Ecol. 89, 157-174.

Jonge, V.N. de \& Essink, K., 1991. Long-term changes in nutrient loads and primary and secondary producers in the Dutch Wadden Sea. In: Estuaries and coasts: spatial and temporal intercomparisons. Ed. by M. Elliott \& J.-P. Ducrotoy. Olsen \& Olsen, Fredensborg, 307-316.

Kreger, D., 1940. On the ecology of Cardium edule L. - Archs. néerl. Zool. 4, 157-200.

Kristensen, I., 1957. Differences in density and growth in a cockle population in the Dutch Wadden Sea. - Archs. néerl. Zool. 12, 351-453.

Madsen, P. B. \& Jensen, K., 1987. Population dynamics of Macoma balthica in the Danish Wadden Sea in an organically enriched area. - Ophelia $27,197-208$.

Officer, C. B., Smayda, T. J. \& Mann, R., 1982. Benthic filter feeding: a natural eutrophication control. - Mar. Ecol. Prog. Ser. 9, 203-210.

Orton, J.H., 1926. On the rate of growth of Cardium edule. Part I. Experimental observations. - J. mar. biol. Ass. U. K. 14, 239-279.

Pejrup, M., Bartholdy, J. \& Jensen, A., 1990. Kvælstof i Grådybs tidevandsområde. - Vand Miljø 2, 47-51.

Reise, K., 1982. Long-term changes in the macrobenthic invertebrate fauna of the Wadden Sea: are polychaetes about to take over? - Neth. J. Sea Res, 16, 29-36.

Reise, K., 1983. Biotic enrichment of intertidal sediments by experimental aggregates of the depositfeeding bivalve Macoma balthica. - Mar. Ecol. Prog. Ser. 12, 229-236.

Reise, K., 1985. Tidal flat ecology. Springer, Berlin, $191 \mathrm{pp.}$

Reise, K., 1987. Distribution and abundance of small and juvenile macrofauna on the tidal flats in the Frisian Wadden Sea. In: Proceedings of the 5th International Wadden Sea Symposium. Ed. by S. Tougaard \& S. Asbirk. The National Forest and Nature Agency \& The Museum of Fishery and Shipping, Esbjerg, 7-25.

Reise, K. \& Schubert, A., 1987. Macrobenthic turnover in the subtidal Wadden Sea: the Norderaue revisited after 60 years. - Helgoländer Meeresunters. 41, 69-82.

Reise, K., Herre, E. \& Sturm, M., 1989. Historical changes in the benthos of the Wadden Sea around the island of Sylt in the North Sea. - Helgoländer Meeresunters. 43, 417-433.

Riesen, W. \& Reise, K., 1982. Macrobenthos of the subtidal Wadden Sea: revisited after 55 years. Helgoländer Meeresunters. 35, 409-423. 
Smidt, E. L. B., 1951. Animal production in the Danish Waddensea. - Meddr Kommn Danm. Fisk.- og Havunders. (Ser. Fiskeri) 11 (6), 1-151.

Stock, J.H., 1952. Some notes on the taxonomy, the distribution and the ecology of four species of the amphipod genus Corophium. - Beaufortia, 21, 1-10.

Swennen, C., Leopold, M. F. \& Stock, M., 1985. Notes on growth and behaviour of the American razor clam Ensis directus in the Wadden Sea and the predation on it by birds. - Helgolander Meeresunters. 39, 255-261.

Thamdrup, H. M., 1935. Beiträge zur Ökologie der Wattenfauna auf experimenteller Grundlage. Meddr Kommn Danm. Fisk. - og Havunders. (Ser. Fiskeri) 10 (2), 1-125.

Veer, H. W. van der, Bergmann, M. J. N. \& Beukema, J. J., 1985. Dredging activities in the Dutch Wadden Sea: effects on macrobenthic infauna. - Neth. J. Sea Res. 19, 183-190.

Urk, R.M. van, 1987. Ensis americanus (Binney) (syn. E. directus Auct. non conrad) a recent introduction from Atlantic North-America. - J. Conch. 32, 329-333.

Vlas, de J., 1987. Effects of cockle fisheries on the macrobenthos in the Wadden Sea. In: Proceedings of the 5th International Wadden Sea Symposium. Ed. by S. Tougaard \& S. Asbirk. The National Forest and Nature Agency \& The Museum of Fishery and Shipping, Esbjerg, 215-227. 